\title{
Effects of irradiance on nitrogen uptake by phytoplankton: comparison of frontal and stratified communities
}

\author{
W. P. Cochlan ${ }^{1,2, *}$, N. M. Price ${ }^{1,3}$, P. J. Harrison ${ }^{1}$ \\ ${ }^{1}$ Department of Oceanography, University of British Columbia, Vancouver, British Columbia, Canada V6T 1W5 \\ ${ }^{2}$ Marine Biology Research Division 0202, Scripps Institution of Oceanography, University of California, San Diego, La Jolla, \\ California 92093, USA \\ ${ }^{3}$ R. M. Parsons Laboratory, Department of Civil Engineering, Massachusetts Institute of Technology, Cambridge, \\ Massachusetts 02139, USA
}

\begin{abstract}
Rates of $\mathrm{NO}_{3}^{-}$and urea uptake by phytoplankton in the shallow and deep chlorophyll layers of the Strait of Georgia, British Columbia (Canada) were measured, over a gradient of photosynthetic photon flux densities (PPFD), using the ${ }^{15} \mathrm{~N}$ tracer technique. The results of these experiments could be fitted with a hyperbolic function similar to the Michaelis-Menten equation and included a term for dark uptake. Half-saturation constants $\left(\mathrm{K}_{\mathrm{LT}}\right)$ for light-dependent uptake of urea and $\mathrm{NO}_{3}^{-}$ranged from 0 to $14 \%$ of the surface PPFD, and dark uptake of both urea and $\mathrm{NO}_{3}^{-}$ranged from 0 to $58 \%$ of the uptake at saturating PPFD. Although the importance of dark uptake increased with increased $\mathrm{N}$ limitation, the dramatic difference in phytoplankton community composition between the N-replete frontal waters and the $\mathrm{N}$-depleted stratified waters precludes a simple explanation of PPFD effect(s) on $\mathrm{N}$ uptake based solely on phytoplankton $\mathrm{N}$ status. The results of this study are compared to those reported for other aquatic systems.
\end{abstract}

\section{INTRODUCTION}

In most marine and freshwater systems, the uptake of nitrogenous nutrients by phytoplankton is related to the availability of the nutrients (e.g. MacIsaac \& Dugdale 1969, Probyn 1985) and to photosynthetic photon flux density (PPFD) (e.g. MacIsaac \& Dugdale 1972, Priscu 1984). The dependence of nitrogen uptake upon PPFD has been described by a rectangular hyperbola similar to the Michaelis-Menten formulation in many marine (e.g. MacIsaac \& Dugdale 1972, Slawyk et al. 1976 ) and freshwater (e.g. Priscu 1984, Whalen \& Alexander 1984) communities. Although nitrogen uptake and assimilation by phytoplankton are dependent upon PPFD as an energy source, either directly or indirectly through photosynthesis, the exact biochemical mechanism(s) by which light regulates nitrogen

\footnotetext{
- Addressee for correspondence: W. P. Cochlan in La Jolla, California
}

metabolism remains unresolved (e.g. see review by Syrett 1981). The presence of $\mathrm{NO}_{3}^{-}$-activated ATPase, apparently located within the cell membranes of a number of marine phytoplankters (Falkowski 1975a,b), provides a physiological basis for the coupling between light and $\mathrm{NO}_{3}^{-}$uptake, and specific ATPases probably exist for the uptake of $\mathrm{NH}_{4}^{+}$and urea as well. The energy (ATP) generated by photophosphorylation is ultimately required for the functioning of these uptake enzymes (permeases) and may also drive the reactions of $\mathrm{NH}_{4}^{+}$(GS/GOGAT) and urea (UAL-ase) assimilation. In addition, the photogeneration of reductants $\mathrm{NAD}(\mathrm{P}) \mathrm{H}$ and reduced ferredoxin will drive the reduction of $\mathrm{NO}_{3}^{-}, \mathrm{NO}_{2}^{-}$and the GOGAT reaction of $\mathrm{NH} 4+$ assimilation. Other possible interactions of light with inorganic nitrogen metabolism of phytoplankton are discussed in detail by Syrett (1981).

Numerous culture studies have demonstrated that Ndeprived phytoplankton have greater dark uptake rates of $\mathrm{N}$ than do N-replete phytoplankton (e.g. Syrett 1962, Eppley \& Coatsworth 1968, Thacker \& Syrett 
1972, Rees \& Syrett 1979), suggesting a lesser light dependence on $\mathrm{N}$ uptake during $\mathrm{N}$ stress. This, together with field studies which show that deep-living phytoplankton sustain substantial $\mathrm{N}$ uptake velocities with little or no light (e.g. Conway \& Whitledge 1979, Nelson \& Conway 1979, Priscu 1984), suggests that both light exposure and nutritional history of phytoplankton may be important in determining their ability to sequester nitrogen, and that these controlling factors may differ for the various forms of nitrogen.

Shallow sea fronts, located at the boundary between stratified and vertically mixed regimes (see reviews by Denman \& Powell 1984, LeFèvre 1986), are generally areas of high primary productivity (e.g. Pingree et al. 1975, Parsons et al. 1981, 1983, Holligan et al. 1984). These regions are characterized by having surface water with high phytoplankton biomass and measurable concentrations of nitrate, and a shallow pycnocline which extends to the surface at the frontal boundary (e.g. Simpson \& Pingree 1978).

A surface transect normal to a frontal boundary progresses from high concentrations of dissolved $\mathrm{NO}_{3}^{-}$on the well-mixed side to $\mathrm{N}$-depleted, stratified waters, and thus represents a gradient of both nitrogen and light availability and consequently of phytoplankton physiological states. Moreover, the nitrogenous nutrition of the phytoplankton would likely differ along such a transect. In the $\mathrm{N}$-impoverished waters, the $\mathrm{N}$ demands of phytoplankton are supplied by reduced $\mathrm{N}$ forms such as $\mathrm{NH}_{4}^{+}$and urea from regenerative processes, whereas in $\mathrm{N}$-rich areas, nitrogen compounds are generally utilized at rates proportional to their availability (e.g. Dugdale \& Goering 1967, McCarthy et al. 1977).

The experiments presented in this study were conducted in the Strait of Georgia, a partially enclosed coastal basin on the west coast of Canada (see reviews by Harrison et al. 1983, LeBlond 1983), where several tidally induced frontal regions have been previously described (Parsons et al. 1981, Price et al. 1985). The influence of PPFD on the uptake of $\mathrm{NO}_{3}^{-}$and urea by phytoplankton from nitrate-replete frontal water and nitrate-depleted stratified water was examined, and the dependence of $\mathrm{N}$ uptake on PPFD by the phytoplankton from the subsurface chlorophyll maximum of these 2 distinct areas was compared. Simulated in situ experimental conditions were attempted in order to obtain a better understanding of the true $\mathrm{NO}_{3}^{-}$uptake response to PPFD in these physically and chemically distinct environments. Most previous studies of the effect(s) of PPFD on $\mathrm{N}$ uptake by phytoplankton have employed saturating enrichments of isotopically labelled $\mathrm{N}$ forms (e.g. MacIsaac \& Dugdale 1972, Priscu 1984, Mitamura 1986), and reported uptake rates may reflect the effects of both PPFD and N concentration.

\section{MATERIALS AND METHODS}

General. Nitrogen uptake experiments were conducted in the Strait of Georgia, B.C., Canada, aboard the CSS 'Vector' during July and August 1984; station locations and names are shown in Fig. 1. Between 14:00 and 15:00 h PDT (Pacific Daylight Time), water samples were collected using 51 PVC Niskin bottles, from just below the sea surface (0 to $1 \mathrm{~m})$ and from depths corresponding to the deep chlorophyll maximum (DCM). The shallow sampling depth represents a light environment of ca 80 to $100 \%$ surface PPFD $\left(\mathrm{I}_{\mathrm{o}}\right)$ for each station, whereas the DCM depth corresponds to ca 8,3 and $2 \% I_{0}$ for Stations T14, A5 and T8, respectively. Samples were shielded from direct sunlight during transfer to 101 Nalgene ${ }^{\circledR}$ carboys and taken into the ship's laboratory. Subsamples for nutrient analyses were removed with an acid-washed syringe and gently filtered through combusted $\left(460{ }^{\circ} \mathrm{C}\right.$ for $4 \mathrm{~h}$ ) Whatman GF/F filters (mounted in $25 \mathrm{~mm}$ Millipore Swinex ${ }^{\circledR}$ filter holders) into acid-washed polyethylene bottles. Nitrate plus nitrite $\left(\mathrm{NO}_{3}^{-}+\mathrm{NO}_{2}^{-}\right)$ and ammonium $\left(\mathrm{NH}_{4}^{+}\right)$were measured immediately with a Technicon AutoAnalyzer ${ }^{\circledR}$ II, following the procedures outlined in Wood et al. (1967) and Slawyk \& MacIsaac (1972), respectively. Urea was determined by the diacetyl monoxime thiosemicarbizide technique described by Price \& Harrison (1987). Samples for chlorophyll a $(\mathrm{chl}$ a) [coefficient of variation $(\mathrm{CV})=$ $4.4 \pm 4.1 \%$; 5 sample pairs] were collected on Whatman GF/F filters and stored frozen in a desiccator. $\mathrm{Chl}$ a was extracted in $90 \%$ acetone overnight and analyzed by in vitro fluorometry (Strickland \& Parsons 1972) using a Turner Designs Model 10 fluorometer. Particulate organic carbon (POC) and nitrogen (PON) $(\mathrm{CV}=5.2 \pm 4.8 \%$ and $3.8 \pm 4.1 \%$ respectively; 7 sample pairs), collected on combusted Whatman GF/F filters, were stored similarly and analyzed later after drying $\left(24 \mathrm{~h}\right.$ at $\left.<60^{\circ} \mathrm{C}\right)$ with a Perkin Elmer Model 240 elemental analyzer, using the dry combustion method described by Sharp (1974).

At each station continuous vertical profiles ( 0 to $20 \mathrm{~m}$ ) of temperature, salinity, fluorescence and $\mathrm{NO}_{3}^{-}+\mathrm{NO}_{2}^{-}$ were run prior to the bottle casts. Temperature and salinity were determined with an InterOcean $514 \mathrm{~A}$ CSTD system; in vivo fluorescence and $\mathrm{NO}_{3}^{-}+\mathrm{NO}_{2}^{-}$ concentrations were obtained from pumped samples (mRoy FR162-144 diaphragm pump, flow rate ca 11 $\min ^{-1}$ ) and measured with a Turner Model 111 fluorometer (equipped with a flow-through cell) and a Technicon AutoAnalyzer ${ }^{\circledR}$ II, respectively. These data were logged onto a computer and plotted in real-time using a custom software programme which compensates for time lags in pumping and machine analyses (Jones et al. in press). Incident solar irradiance (PAR, 
Fig. 1. Station locations for nitrogen uptake experiments. Frontal (T14), shallow stratified (A5) and deeply stratified (T8) stations in the Strait of Georgia, British Columbia

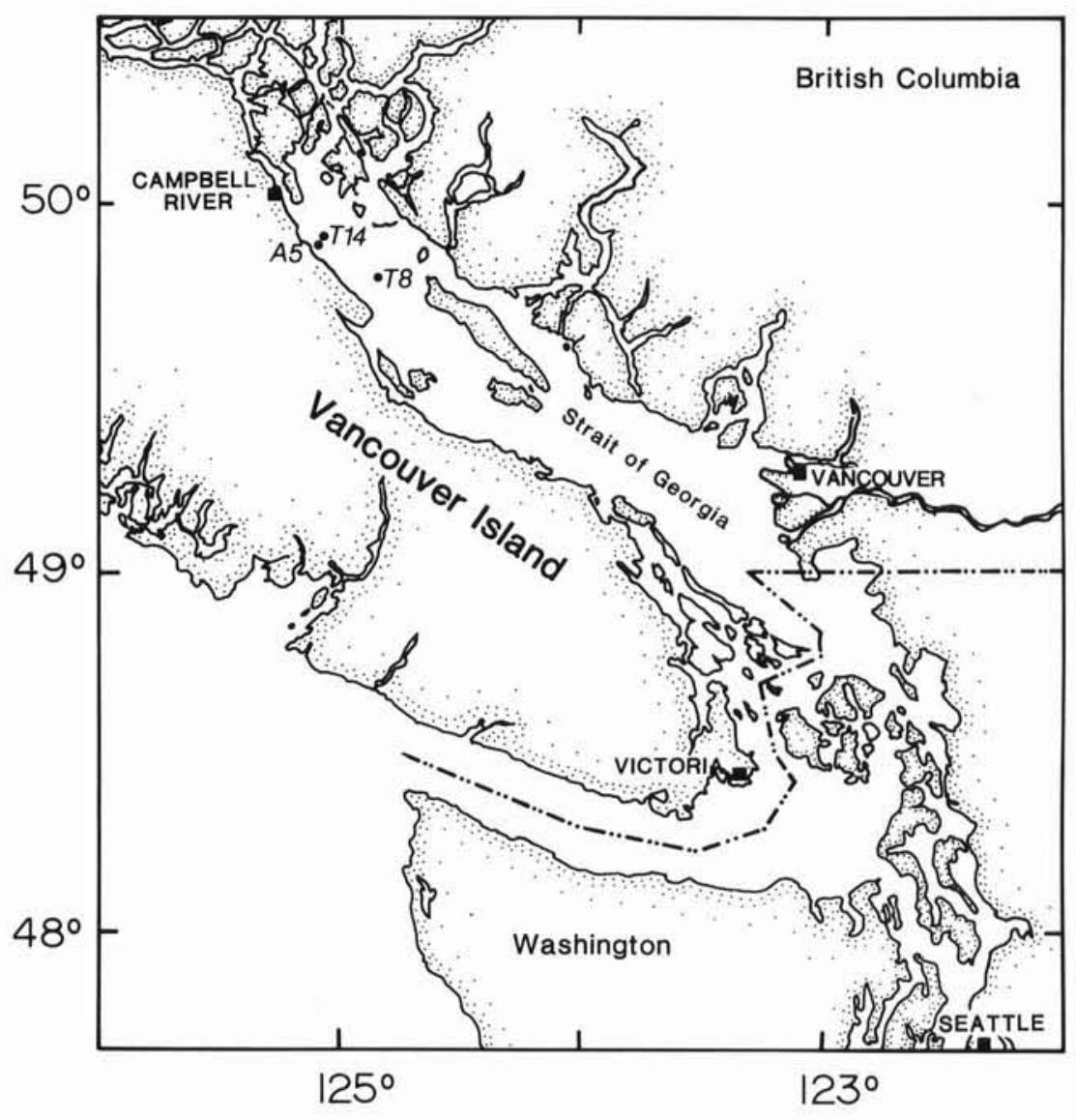

associated with the urea uptake experiments. Following enrichment, bottles were immediately mixed and placed within neutral-density screening to simulate the following PPFDs: 95, 55, 31, 10, 3.4, 1.1 and $0 \% \mathrm{I}_{\mathrm{o}}$. The screen material used in the incubators was calibrated with a Biospherical Instruments QSL-100 $4 \pi$ sensor placed within an incubation bottle. The $0 \%$ PPFD was achieved by multiple wrappings of the bottle with black tape. Incubations were conducted at in situ temperatures $\left( \pm 1.5^{\circ} \mathrm{C}\right)$ under natural light in clear, Plexiglas ${ }^{\circledR}$ deck incubators. Clear, cloudless skies prevailed throughout the cruise, resulting in virtually identical ambient light conditions during each experiment. Samples from the surface waters were cooled with flowing surface seawater, while deeper samples were incubated in a separate, temperature-controlled incubator. Incubations were terminated after 2 to $4 \mathrm{~h}$ by filtration (pressure differential $<125 \mathrm{~mm} \mathrm{Hg}$ ) onto combusted Whatman GF/F filters, placed into plastic petri dishes, and stored frozen in a desiccator. Based on the ambient dissolved nitrogen concentration, the initial particulate nitrogen concentration, and the final ${ }^{15} \mathrm{~N}$ atom percentage in the particulate fraction, it was calculated that a mean $( \pm \mathrm{SD})$ of $24.1 \pm 15.3 \%$ and $8.5 \pm 5.2 \%$ of the $\mathrm{NO}_{3}^{-}$and urea, respectively, in solution was incorporated into particulate material during 
the incubation period. Substrate exhaustion was therefore not considered a problem in the experiments of this study.

Nitrogen in the particulate samples was converted to dinitrogen gas $\left(\mathrm{N}_{2}\right)$ by the micro-Dumas dry combustion technique (La Roche 1983) and then analyzed for ${ }^{15} \mathrm{~N}$ enrichment with a JASCO Model N-150 emission spectrometer (Fiedler \& Proksch 1975). Generally, each sample was scanned 6 times (minimum of 3 times), and the average ${ }^{15} \mathrm{~N} /{ }^{14} \mathrm{~N}$ peak height ratio was used in the calculation of the atom percent ${ }^{15} \mathrm{~N}$ (specific activity) in the particulate material. Automatic selection of peak heights during scans, and isotopic ratio calculations, were performed utilizing in-house software (Jones unpubl.) on an IBM-compatible PC interfaced with the spectrometer. The emission spectrometer was routinely calibrated with a series of pure $\mathrm{N}_{2}$ gas standards supplied by JASCO of known ${ }^{15} \mathrm{~N}$ enrichment.

Nitrogen uptake rates were calculated using Equation 7 of Dugdale \& Wilkerson (1986) (equivalent to Equation 5 of Collos 1987), which corrects for changes in PON during the incubation period. Corrections were not made for isotopic dilution from remineralization of ${ }^{14} \mathrm{~N}$-urea during the incubation (Hansell \& Goering 1989), as this correction would probably be negligible given the large amount of ${ }^{15} \mathrm{~N}$-labelled urea added to the bottles. Specific rates of nitrogen transport were calculated by dividing the volumetric rates by the phaeophytin-corrected chl a concentration at the beginning of the experiments. Although chl a per cell may vary with depth due to PPFD differences, it was chosen as the normalization parameter because it absorbs the light necessary to fuel cellular transport mechanisms. Use of chl a specific uptake rates also facilitates comparison with previously published studies on chl a normalized nitrogen and carbon uptake vs irradiance.
Kinetic parameters of uptake. The kinetic constants for $\mathrm{NO}_{3}^{-}$and urea uptake with respect to irradiance were obtained by a direct fit of the data to a modified Michaelis-Menten hyperbola using a computerized, iterative, non-linear least-squares technique (Labtec Notebook Curvefit ${ }^{\circledR}$, Laboratories Technologies Corp.). The Michaelis-Menten equation, modified to account for dark uptake, describes uptake over the hyperbolic part of the curve (MacIsaac \& Dugdale 1972) and is as follows:

$$
\mathrm{V}=\mathrm{V}_{\mathrm{D}}+\mathrm{V}_{\max }^{\prime}\left[\frac{\mathrm{I}}{\mathrm{K}_{\mathrm{LT}}+\mathrm{I}}\right]
$$

where $\mathrm{V}=$ total uptake of $\mathrm{N}$ per unit of chlorophyll; $\mathrm{V}_{\mathrm{D}}$ $=$ dark value of $\mathrm{V}_{i} \mathrm{I}=$ integrated average PPFD during the incubation period; $\mathrm{V}_{\text {max }}^{\prime}=$ maximum $\mathrm{N}$ uptake per unit chlorophyll at saturating PPFD; and $\mathrm{K}_{\mathrm{LT}}$ (the halfsaturation constant for light) $=$ PPFD at $0.5 \mathrm{~V}_{\text {max }}^{\prime}$. The assumption is made that dark uptake is a constant at all light levels. Only data obtained from non-photoinhibitory PPFDs were used in this analysis.

\section{RESULTS AND DISCUSSION}

\section{General description of stations}

The vertical profiles of temperature, salinity, relative in vivo chl a fluorescence and $\mathrm{NO}_{3}^{-}+\mathrm{NO}_{2}^{-}$concentration, for the 3 stations at which $\mathrm{N}$ uptake vs PPFD experiments were conducted, are presented in Fig. 2. The diagnostic features of the frontal water (Station T14) included a weak thermocline and halocline which extended from the surface to ca $9 \mathrm{~m}$, a subsurface fluorescence maximum layer (ca 5 to $8 \mathrm{~m}$ ), a nitracline which extended to the surface, and relatively high $\mathrm{NO}_{3}^{-}$ $+\mathrm{NO}_{2}^{-}$concentrations throughout the water column.

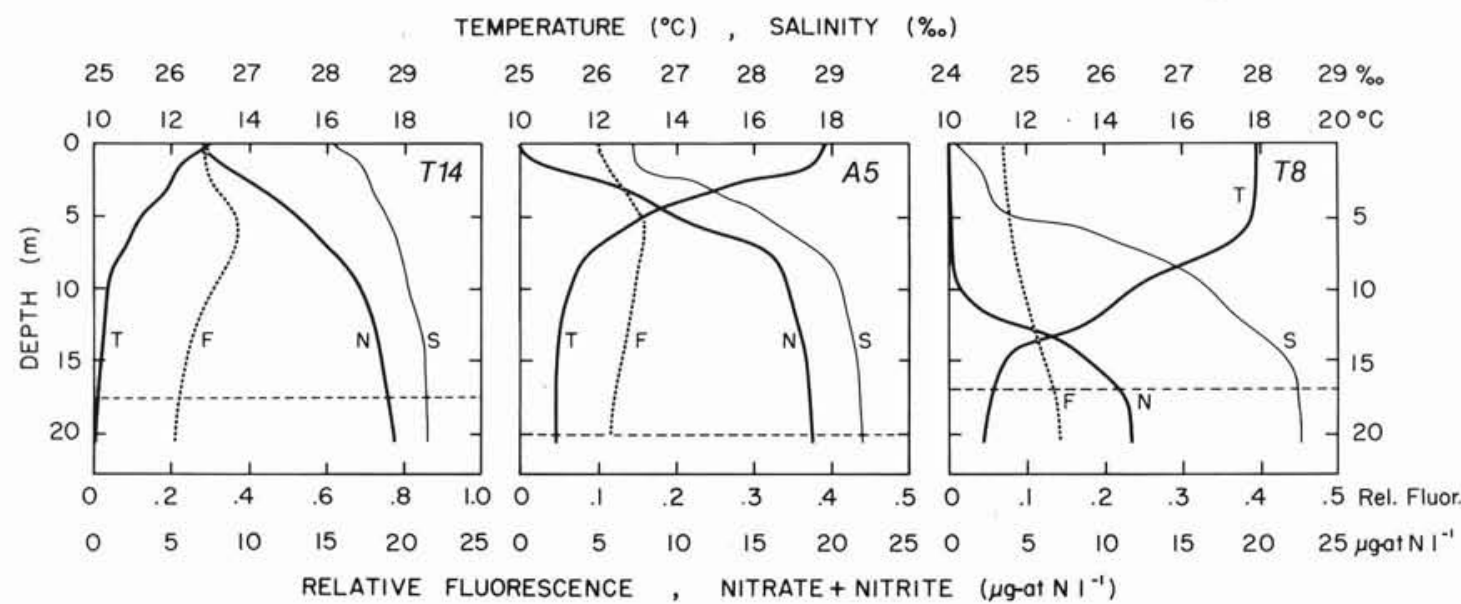

Fig. 2. Depth profiles of temperature $(T)$, salinity $(S)$, in vivo fluorescence $(F)$ and nitrate plus nitrite concentration $(N)$ for the 3 stations sampled (T14: frontal; A5: shallow stratified; T8: deeply stratified). The horizontal dashed line denotes the depth of $1 \%$ surface PPFD (photosynthetic photon flux density) 
Table 1. Initial environmental conditions of seawater collected for N-uptake vs irradiance experiments. PDT: Pacific Daylight Time; Chl a: chlorophyll a; PON: particulate organic nitrogen; POC: particulate organic carbon; (-): not determined

\begin{tabular}{|c|c|c|c|c|c|c|c|c|c|c|c|}
\hline \multirow{2}{*}{\multicolumn{2}{|c|}{$\begin{array}{l}\text { Station } \\
\text { and } \\
\text { location }\end{array}$}} & \multirow{3}{*}{$\begin{array}{l}\text { Description } \\
\text { Frontal }\end{array}$} & \multirow{3}{*}{$\begin{array}{c}\text { Date } \\
(1984) \\
\\
27 \mathrm{Jul}\end{array}$} & \multirow{3}{*}{$\begin{array}{c}\begin{array}{c}\text { Starting } \\
\text { time of } \\
\text { incubation } \\
\text { (PDT) }\end{array} \\
15: 30 \mathrm{~h}\end{array}$} & \multirow{3}{*}{$\begin{array}{c}\begin{array}{c}\text { Sample } \\
\text { depth } \\
(\mathrm{m})\end{array} \\
0 \\
\end{array}$} & \multicolumn{3}{|c|}{ Nitrogen conc. } & \multirow{3}{*}{$\begin{array}{c}\begin{array}{c}\text { Chl a } \\
\left(\mu \mathrm{g}^{-1}\right)\end{array} \\
1.29 \\
2.28\end{array}$} & \multirow{3}{*}{ 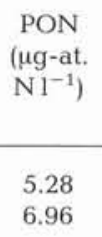 } & \multirow{3}{*}{$\begin{array}{c}\begin{array}{c}\text { POC } \\
(\mu g-a t . \\
\left.C^{-1}\right)\end{array} \\
43.1 \\
40.6\end{array}$} \\
\hline & & & & & & $\mathrm{NO}_{3}^{-}$ & $\begin{array}{c}\text { Urea } \\
\left(\mu \mathrm{g} \text {-at. } \mathrm{NI}^{-1}\right)\end{array}$ & $\mathrm{NH}_{4}{ }^{+\mathrm{a}}$ & & & \\
\hline T14 & $\begin{array}{r}49^{\circ} 53^{\prime} 24^{\prime \prime} \mathrm{N} \\
125^{\circ} 05^{\prime} 06^{\prime \prime} \mathrm{W}\end{array}$ & & & & & $\begin{array}{c}6.02 \\
15.05\end{array}$ & - & $\begin{array}{l}0.23 \\
0.21\end{array}$ & & & \\
\hline A5 & $\begin{array}{r}49^{\circ} 53^{\prime} 02^{\prime \prime} \mathrm{N} \\
125^{\circ} 05^{\prime} 48^{\prime \prime} \mathrm{W}\end{array}$ & $\begin{array}{l}\text { Shallow } \\
\text { stratified }\end{array}$ & 30 Jul & $14: 30 \mathrm{~h}$ & $\begin{array}{r}0 \\
15\end{array}$ & $\begin{array}{r}<.05 \\
20.89\end{array}$ & $\begin{array}{l}0.63 \\
0.72\end{array}$ & $\begin{array}{l}0.16 \\
0.32\end{array}$ & $\begin{array}{l}0.33 \\
0.67\end{array}$ & $\begin{array}{l}2.57 \\
2.01\end{array}$ & $\begin{array}{l}22.9 \\
14.5\end{array}$ \\
\hline T8 & $\begin{array}{r}49^{\circ} 48^{\prime} 36^{\prime \prime} \mathrm{N} \\
124^{\circ} 50^{\prime} 39^{\prime \prime} \mathrm{W}\end{array}$ & $\begin{array}{l}\text { Deep } \\
\text { stratified }\end{array}$ & $1 \mathrm{Aug}$ & $15: 00 \mathrm{~h}$ & $\begin{array}{r}0 \\
15\end{array}$ & $\begin{array}{l}<.05 \\
7.54\end{array}$ & $\begin{array}{l}0.82 \\
0.17\end{array}$ & $\begin{array}{l}0.17 \\
0.40\end{array}$ & $\begin{array}{l}0.35 \\
0.99\end{array}$ & $\begin{array}{l}2.90 \\
3.83\end{array}$ & $\begin{array}{l}24.1 \\
24.1\end{array}$ \\
\hline
\end{tabular}

In the deeply stratified station (T8), fluorescence increased slightly with depth; the nitracline occurred at ca $12 \mathrm{~m}$, and the upper $10 \mathrm{~m}$ was devoid of measurable $\mathrm{NO}_{3}^{-}+\mathrm{NO}_{2}^{-}$. A strong thermocline and halocline at 5 to $15 \mathrm{~m}$ separated the deep $\mathrm{NO}_{3}^{-}$-replete water from the $\mathrm{NO}_{3}^{-}$-depleted mixed surface water. Similar conditions were observed at the shallow stratified station (A5), but the halocline, thermocline, and nitracline all developed within the upper $5 \mathrm{~m}$ of the water column. The initial biomass data and environmental conditions for each station are given in Table 1.

The species composition of the phytoplankton community in the frontal and stratified waters varied considerably (Table 2). In the frontal waters, large, chainforming diatoms were the most common phytoplankton at both the surface and the DCM layer. Chaetoceros socialis was the dominant species, followed in abundance by Skeletonema costatum and other diatoms of the genus Chaetoceros, including $C$. debilis. Small pigmented flagellates $(<5 \mu \mathrm{m})$ were the most abundant phytoplankton in the surface waters of both stratified stations (A5 and T8); dominant diatoms were still $S$. costatum and Chaetoceros spp., although Thalassiosira spp. and pennate diatoms belonging to the genera Navicula and Nitzschia appeared in small numbers.

Table 2. Phytoplankton community composition in frontal and stratified water in the Strait of Georgia, B.C., Canada. Phytoplankton density given $\times 10^{6}$ cells $1^{-1}$

\begin{tabular}{|c|c|c|c|}
\hline \multirow[t]{2}{*}{ Station } & \multirow[t]{2}{*}{ Depth (m) } & \multicolumn{2}{|c|}{ Phytoplankton } \\
\hline & & Diatoms & Flagellates $^{a}$ \\
\hline \multirow[t]{2}{*}{ Frontal T14 } & 0 & 2.3 & 0.96 \\
\hline & 8 & 2.2 & 0.76 \\
\hline \multirow[t]{2}{*}{ Shallow stratified A5 } & 0 & 0.23 & 1.9 \\
\hline & 15 & 0.73 & 0.79 \\
\hline \multirow[t]{2}{*}{ Deeply stratified T8 } & 0 & 0.026 & 1.5 \\
\hline & 15 & 0.15 & 1.7 \\
\hline
\end{tabular}

Dinoflagellates were always a small numerical fraction $(<5 \%)$ of the total flagellates present and were almost exclusively Gymnodinium or Amphidinium spp. The DCM communities of the 2 stratified stations differed in the relative abundance of flagellates and diatoms, but the species composition was similar.

\section{Effect of irradiance on nitrogen uptake rates}

MacIsaac \& Dugdale (1972) first showed that the uptake of nitrate and ammonium by natural phytoplankton assemblages could be related to PPFD by a rectangular hyperbola; PPFD may be treated as a substrate, following Michaelis-Menten kinetics, under conditions of no nutrient stress. Such a model assumes that there is no $\mathrm{N}$ uptake at 0 PPFD (i.e. the PPFD response curve passes through the origin). They suggested that the consequences of not subtracting dark uptake from light uptake, when uptake in the dark is greater than ca $15 \%$ of uptake at saturating PPFD, can be significant; linear transformations of such kinetic data are distorted beyond usefulness and thus the values of derived parameters are questionable. For situations in which dark uptake is a substantial portion $(>10$ to $15 \%$ of PPFD - saturated uptake), they proposed a slightly modified equation, employed in the present study, which takes into account a constant dark uptake rate and describes $\mathrm{N}$ uptake over the hyperbolic portion of the PPFD response curve, but not photoinhibition. Photoinhibition problems can be overcome by using either an equation developed by Parker (1974) or a modification of the equation of Platt et al. (1980), originally developed for the light response of photosynthesis (Lewis \& Levine 1984, Dodds \& Priscu 1989, Priscu 1989). Numerous studies in both marine (MacIsaac \& Dugdale 1972, MacIsaac et al. 1974, Nelson \& Conway 1979, Slawyk 1979, Kanda et al. 1989) and freshwater (Priscu 1984, Whalen \& Alexander 1984, Mitamura 1986) natural communities have 
demonstrated that the response in uptake of $\mathrm{NO}_{3}^{-}$and $\mathrm{NH}_{4}^{+}$can be described by the Michaelis-Menten formulation.

In the present study, nitrate and urea uptake were dependent on PPFD at both depths sampled in stratified and frontal waters of the Strait of Georgia. Experiments in which the natural phytoplankton communities from the surface and DCM layers were exposed to a gradient in PPFD yielded data which could be adequately described by the Michaelis-Menten formulation, up to inhibiting PPFD levels (Figs. 3 and 4). Photoinhibition occurred between 55 and $95 \%$

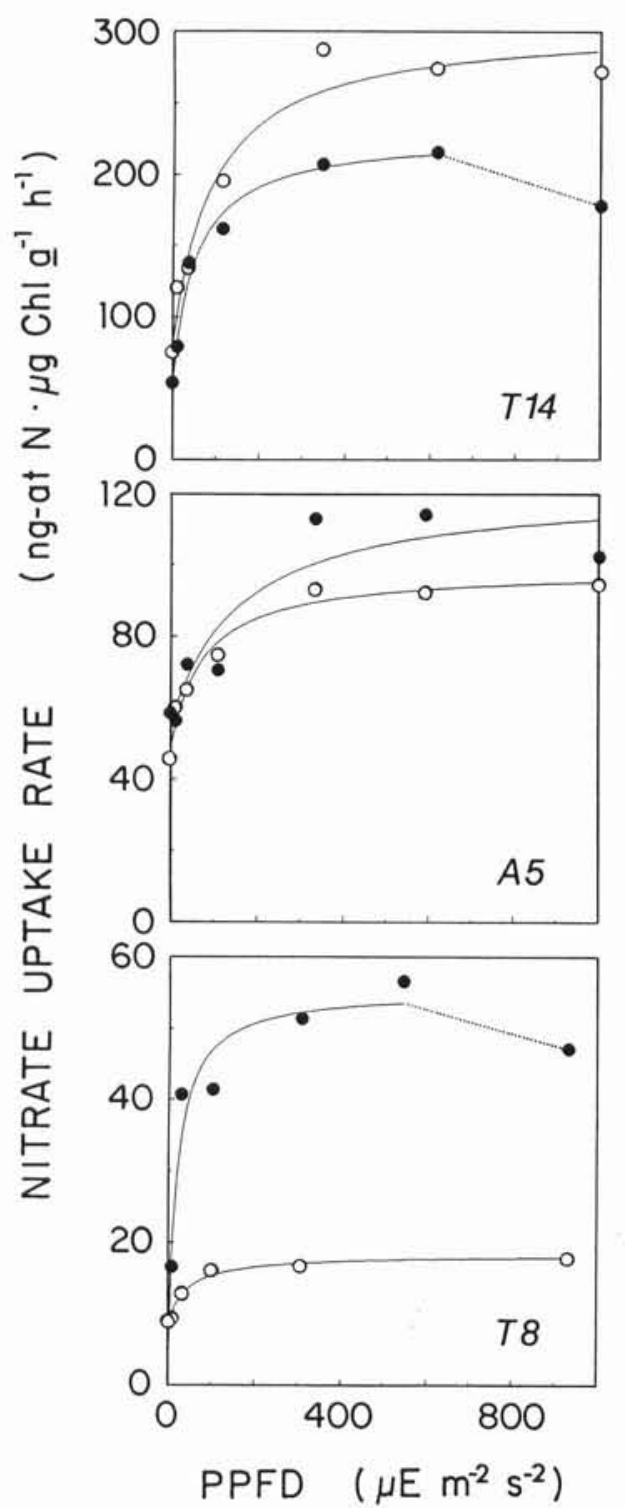

Fig. 3. Nitrate uptake of the surface $(\circ)$ and DCM $(\bullet)$ phytoplankton communities of the Strait of Georgia, British Columbia. The curved plots are fitted directly to the MichaelisMenten equation; the linear (dotted line) PPFD-inhibited portions were not included in the calculations. Stations are T14: frontal; A5: shallow stratified; and T8: deeply stratified of $I_{o}$ and was only observed for samples collected from the DCM layers. Photoinhibition of $\mathrm{N}$ uptake cannot be adequately discussed in this study due to the paucity of data at high PPFD, but suffice it to say that it is probably not a problem for the surface samples, which are naturally exposed to high PPFD; phytoplankton collected near the bottom of the euphotic zone are effectively excluded from the high PPFD in the mixed surface waters by the pycnocline and are not likely to encounter such high PPFDs naturally.

\section{Kinetic parameters of nitrogen uptake}

Dark uptake, the half-saturation constant $\left(\mathrm{K}_{\mathrm{LT}}\right)$, and maximum nitrogen uptake velocity $\left(\mathrm{V}^{\prime}{ }_{\max }\right)$ for lightdependent urea and nitrate uptake are summarized in Table 3 . The $\mathrm{K}_{\mathrm{LT}}$ values in Table 3 are those representing the PPFD at which $0.5 \mathrm{~V}_{\max }^{\prime}$ occurs. However, it is important to remember that these Michaelis-Menten parameters only represent uptake data from the hyperbolic (or light) portion of the PPFD response curve and do not include the substantial dark $\mathrm{N}$ uptake observed. Some investigators (e.g. Priscu 1984) have ignored dark uptake in the linear transformation of their kinetic data and forced their PPFD response curves to pass through the origin even though dark uptake was substantial (ca $50 \%$ of total $\mathrm{N}$ uptake). Half-saturation constants derived in this manner are not an accurate

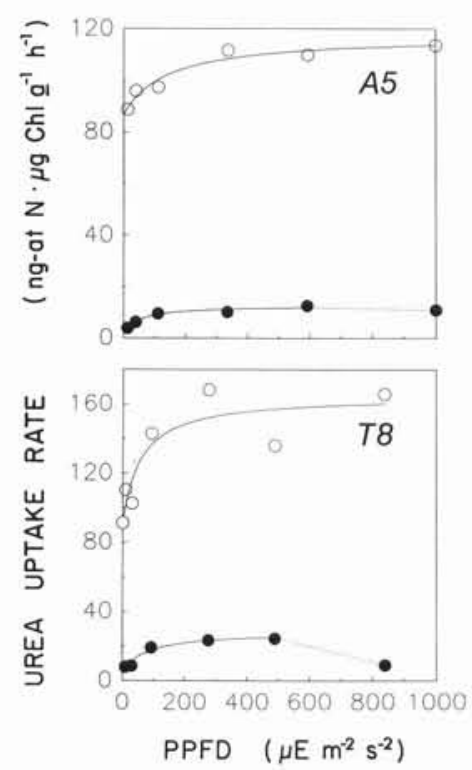

Fig. 4. Urea uptake of surface $(0)$ and DCM $(\bullet)$ phytoplankton communities of the Strait of Georgia. The curved plots are fitted directly to the Michaelis-Menten equation; the linear (dotted line) PPFD-inhibited portions were not included in the calculations. A5: shallow stratified station; T8: deeply stratified station 
Table 3. Parameters describing the characteristics of nitrogen uptake, as a function of PPFD (photosynthetic photon flux density), for phytoplankton assemblages in the Strait of Georgia, B.C., Canada. Stations are T14: frontal; A5: shallow stratified; and T8: deeply stratified. Definitions of $\mathrm{V}_{\mathrm{D}}, \mathrm{V}^{\prime}$ max and $\mathrm{K}_{\mathrm{LT}}$ are given in the 'Materials and Methods'; estimated standard errors of parameters are shown in parentheses

\begin{tabular}{|c|c|c|c|c|c|c|c|c|c|c|}
\hline \multirow{3}{*}{$\begin{array}{l}\text { Station } \\
\text { T14 }\end{array}$} & \multirow{3}{*}{$\begin{array}{l}\begin{array}{l}\text { Nitrogen } \\
\text { substrate }\end{array} \\
\mathrm{NO}_{3}{ }^{-}\end{array}$} & \multirow{3}{*}{$\begin{array}{c}\begin{array}{c}\text { Depth } \\
\text { (m) }\end{array} \\
0 \\
8\end{array}$} & \multirow{2}{*}{\multicolumn{4}{|c|}{$\begin{array}{l}\mathrm{V}_{\mathrm{D}} \\
\text { [ng-at. } \mathrm{N}(\mu \mathrm{g} \text { chl } a)^{-1} \mathrm{~h}^{-1} \text { ] }\end{array}$}} & \multicolumn{4}{|c|}{$\mathrm{K}_{\mathrm{LT}}$} \\
\hline & & & & & & & \multicolumn{2}{|c|}{$\mu \mathrm{E} \mathrm{m}^{-2} \mathrm{~s}^{-1}$} & \multicolumn{2}{|c|}{$\% \mathrm{I}_{\mathrm{o}}$} \\
\hline & & & $\begin{array}{l}80 \\
53\end{array}$ & $\begin{array}{l}(16.8) \\
(9.4)\end{array}$ & $\begin{array}{l}225 \\
174\end{array}$ & $\begin{array}{l}(22.3) \\
(12.5)\end{array}$ & $\begin{array}{l}91 \\
53\end{array}$ & $\begin{array}{l}(40.1) \\
(15.7)\end{array}$ & $\begin{array}{l}8.2 \\
4.8\end{array}$ & $\begin{array}{l}(3.6) \\
(1.4)\end{array}$ \\
\hline \multirow[t]{2}{*}{ A5 } & $\mathrm{NO}_{3}{ }^{-}$ & $\begin{array}{r}0 \\
15\end{array}$ & $\begin{array}{l}48 \\
55\end{array}$ & $\begin{array}{l}(3.2) \\
(8.8)\end{array}$ & $\begin{array}{l}50 \\
67\end{array}$ & $\begin{array}{l}(4.0) \\
(15.3)\end{array}$ & $\begin{array}{r}74 \\
156\end{array}$ & $\begin{array}{l}(25.9) \\
(151)\end{array}$ & $\begin{array}{l}6.7 \\
14\end{array}$ & $\begin{array}{l}(2.3) \\
(14)\end{array}$ \\
\hline & Urea & $\begin{array}{r}0 \\
15\end{array}$ & $\begin{array}{l}87 \\
1.8\end{array}$ & $\begin{array}{l}(4.2) \\
(2.3)\end{array}$ & $\begin{array}{l}31 \\
11\end{array}$ & $\begin{array}{l}(4.3) \\
(1.9)\end{array}$ & $\begin{array}{r}140 \\
54\end{array}$ & $\begin{array}{l}(103) \\
(40.7)\end{array}$ & $\begin{array}{c}13 \\
4.9\end{array}$ & $\begin{array}{l}(9.3) \\
(3.7)\end{array}$ \\
\hline \multirow[t]{2}{*}{ T8 } & $\mathrm{NO}_{3}{ }^{-}$ & $\begin{array}{r}0 \\
15\end{array}$ & $\begin{array}{l}8.5 \\
0\end{array}$ & $(0.79)$ & $\begin{array}{c}9.8 \\
55\end{array}$ & $\begin{array}{l}(1.02) \\
(4.2)\end{array}$ & $\begin{array}{l}45 \\
18\end{array}$ & $\begin{array}{l}(18.7) \\
(6.6)\end{array}$ & $\begin{array}{l}4.6 \\
1.8\end{array}$ & $\begin{array}{l}(1.9) \\
(0.7)\end{array}$ \\
\hline & Urea & $\begin{array}{r}0 \\
15\end{array}$ & $\begin{array}{l}92 \\
4.0\end{array}$ & $\begin{array}{l}(14.1) \\
(3.9)\end{array}$ & $\begin{array}{l}73 \\
24\end{array}$ & $\begin{array}{l}(17.6) \\
(3.6)\end{array}$ & $\begin{array}{l}59 \\
72\end{array}$ & $\begin{array}{l}(63.4) \\
(56.2)\end{array}$ & $\begin{array}{l}6.7 \\
8.2\end{array}$ & $\begin{array}{l}(7.2) \\
(6.4)\end{array}$ \\
\hline
\end{tabular}

measure of the PPFD at which $\mathrm{V}=\mathrm{V}^{\prime}{ }_{\max } / 2$ and should be interpreted with caution, particularly as an indicator of the phytoplankton communities' abilities to assimilate specific $\mathrm{N}$ substrates at low PPFD. A better estimate of the PPFD at which one-half the total maximal N uptake (light + dark) of the phytoplankton community is achieved $\left(\mathrm{K}_{\mathrm{LT}}{ }^{\prime}\right)$ can be calculated by a simple rearrangement of the Michaelis-Menten equation employed in the present study:

$$
\mathrm{K}_{\mathrm{LT}}=\left(\mathrm{V}-\mathrm{V}_{\mathrm{D}}\right) \times \mathrm{K}_{\mathrm{LT}} /\left(\mathrm{V}_{\text {max }}^{\prime}-\mathrm{V}+\mathrm{V}_{\mathrm{D}}\right)
$$

where $\mathrm{V}=\left(\mathrm{V}_{\text {max }}^{\prime}+\mathrm{V}_{\mathrm{D}}\right) / 2 ; \mathrm{V}_{\text {max }}^{\prime}=$ maximum uptake described by the rectangular hyperbola; $\mathrm{K}_{\mathrm{LT}}=$ its halfsaturation constant; $V_{D}=$ dark uptake rate. Alternatively, another half-saturation constant, $\mathrm{K}_{\mathrm{LT}}{ }^{\prime \prime}$, can be calculated by substituting $\mathrm{V}$ for one-half the velocity of total $\mathrm{N}$ uptake (light + dark) at saturating PPFD, according to Equation 1. Both of these derived halfsaturation constants will generate values that are more realistic measures of the PPFD at one-half the actual maximum $\mathrm{N}$ uptake taking place in the phytoplankton community, since they include dark uptake (Table 4).

The values of the half-saturation constant for $\mathrm{NO}_{3}^{-}$ uptake in the present study, with or without the correction for dark uptake, range from 0 to $14 \% \mathrm{I}_{\mathrm{o}}$ ( 0 to 156 $\mu \mathrm{E} \mathrm{m}^{-2} \mathrm{~s}^{-1}$ ), which is consistent with previously published values for marine and freshwater natural phytoplankton assemblages (Table 5). The half-saturation values for urea uptake are similar, ranging from 0 to 13 $\% \mathrm{I}_{\mathrm{o}}\left(0\right.$ to $\left.140 \mu \mathrm{E} \mathrm{m}^{-2} \mathrm{~s}^{-1}\right)$. Previously published kinetic studies for urea are few. Webb \& Haas (1976) report a $\mathrm{K}_{\mathrm{LT}}$ of ca 0.01 langley $\mathrm{min}^{-1}\left(35 \mu \mathrm{E} \mathrm{m}^{-2} \mathrm{~s}^{-1}\right)$ for phytoplankton from the York River estuary in Virginia, USA, during the summer, although values in the autumn

Table 4. Indices of $\mathrm{N}$ uptake dependency on PPFD (photosynthetic photon flux density) for phytoplankton in the Strait of Georgia: ratio of dark to light-saturated total uptake rate $\left(\mathrm{V}_{\mathrm{D}}: \mathrm{V}_{\mathrm{L}}\right)$; the PPFD at which half of total $\mathrm{N}$ uptake occurs $\left(\mathrm{K}_{\mathrm{LT}}{ }^{\prime}, \mathrm{K}_{\mathrm{LT}}{ }^{\prime \prime}\right.$ - see definitions in 'Results and Discussion: Kinetic parameters of nitrogen uptake'); and ratio of uptake under $1 \% \mathrm{I}_{\mathrm{o}}$ (surface PPFD) to that under $55 \% \mathrm{I}_{\mathrm{o}}\left(\mathrm{V}_{1 \%}: \mathrm{V}_{55 \%}\right)$. The $\mathrm{K}_{\mathrm{LT}}$ values are expressed as PPFD values $\left(\mu \mathrm{E} \mathrm{m}^{-2} \mathrm{~s}^{-1}\right)$ and as a percentage of $\mathrm{I}_{\mathrm{o}}$ (shown in parentheses)

\begin{tabular}{|c|c|c|c|c|c|c|c|c|}
\hline \multirow{2}{*}{$\begin{array}{c}\text { Station } \\
\text { T14 }\end{array}$} & \multirow{2}{*}{$\begin{array}{c}\begin{array}{c}\text { Nitrogen } \\
\text { substrate }\end{array} \\
\mathrm{NO}_{3}^{-}\end{array}$} & \multirow{2}{*}{$\begin{array}{c}\begin{array}{c}\text { Depth } \\
\text { (m) }\end{array} \\
0 \\
8\end{array}$} & \multirow{2}{*}{$\begin{array}{c}\mathrm{V}_{\mathrm{D}}: \mathrm{V}_{\mathrm{L}} \\
0.28 \\
0.25\end{array}$} & \multicolumn{2}{|c|}{$\mathrm{K}_{\mathrm{LT}}{ }^{\prime}$} & \multicolumn{2}{|c|}{$\mathrm{K}_{\mathrm{LT}}{ }^{\prime \prime}$} & \multirow{2}{*}{$\begin{array}{c}\mathrm{V}_{1 \%}: \mathrm{V}_{55 \%} \\
0.38 \\
0.40\end{array}$} \\
\hline & & & & $\begin{array}{l}36 \\
24\end{array}$ & $\begin{array}{l}(3.2) \\
(2.1)\end{array}$ & $\begin{array}{l}43 \\
28\end{array}$ & $\begin{array}{l}(3.9) \\
(2.5)\end{array}$ & \\
\hline \multirow[t]{2}{*}{ A5 } & $\mathrm{NO}_{3}^{-}$ & $\begin{array}{r}0 \\
15\end{array}$ & $\begin{array}{l}0.51 \\
0.49\end{array}$ & $\begin{array}{l}0 \\
3.0\end{array}$ & $\overline{(0.3)}$ & $\begin{array}{c}1.6 \\
15\end{array}$ & $\begin{array}{l}(0.1) \\
(1.3)\end{array}$ & $\begin{array}{l}0.60 \\
0.56\end{array}$ \\
\hline & Urea & $\begin{array}{r}0 \\
15\end{array}$ & $\begin{array}{l}0.77 \\
0.15\end{array}$ & $\begin{array}{r}0 \\
33\end{array}$ & $\overline{(3.0)}$ & $\begin{array}{r}0 \\
39\end{array}$ & 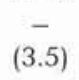 & $\begin{array}{l}0.80 \\
0.33\end{array}$ \\
\hline \multirow[t]{2}{*}{ T8 } & $\mathrm{NO}_{3}^{-}$ & $\begin{array}{r}0 \\
15\end{array}$ & $\begin{array}{l}0.48 \\
0\end{array}$ & $\begin{array}{l}1.9 \\
0\end{array}$ & $\begin{array}{c}(0.2) \\
-\end{array}$ & $\begin{array}{l}3.1 \\
0\end{array}$ & $\begin{array}{c}(0.3) \\
-\end{array}$ & $\begin{array}{l}0.60 \\
0.37\end{array}$ \\
\hline & Urea & $\begin{array}{r}0 \\
15\end{array}$ & $\begin{array}{l}0.58 \\
0.16\end{array}$ & $\begin{array}{r}0 \\
39\end{array}$ & $\frac{-}{(4.5)}$ & $\begin{array}{r}0 \\
52\end{array}$ & $\frac{-}{(5.8)}$ & $\begin{array}{l}0.65 \\
0.28\end{array}$ \\
\hline
\end{tabular}


ranged from 0.02 to 0.12 langley $\min ^{-1}$ (69 to $418 \mu \mathrm{E}$ $\mathrm{m}^{-2} \mathrm{~s}^{-1}$ ). A similar summer $\mathrm{K}_{\mathrm{LT}}$ value was reported by Mitamura (1986) for urea uptake by phytoplankton from oligotrophic Lake Biwa in Japan (2.44 Kilolux = $39 \mu \mathrm{E} \mathrm{m}^{-2} \mathrm{~s}^{-1}$ ). Mitamura also reported a similar $\mathrm{K}_{\mathrm{LT}}$ value for $\mathrm{NH}_{4}^{+}$uptake $\left(28 \mu \mathrm{E} \mathrm{m}^{-2} \mathrm{~s}^{-1}\right)$ and a greater $\mathrm{K}_{\mathrm{LT}}$ value for nitrate uptake $\left(67 \mu \mathrm{E} \mathrm{m}^{-2} \mathrm{~s}^{-1}\right)$. Interpretation of the small differences in the half-saturation constants of the present study, either between $\mathrm{N}$ substrates or between the communities taken from different depths, is rather difficult. However, this kinetic parameter has been included for purposes of literature comparison. (Previously published values were converted to $\mu \mathrm{E} \mathrm{m}^{-2}$ $\mathrm{s}^{-1}$, according to the conversions in the footnotes to Table 5. The reader is cautioned that conversions between units of illumination and energy to quanta are complicated and, due to the varying nature of these measurements, imprecise.)

A simpler and more straightforward index for assessing the effect of PPFD on $\mathrm{N}$ uptake can be determined by comparing total $\mathrm{N}$ uptake, calculated according to Equation 1, at low $\left(1 \% \mathrm{I}_{\mathrm{o}}\right)$ and at saturating $\left(55 \% \mathrm{I}_{\mathrm{o}}\right)$ PPFD (Conway \& Whitledge 1979); lower percentages represent greater PPFD dependency. At the frontal station (T14) both surface and DCM communities had the same PPFD dependency for $\mathrm{NO}_{3}^{-}$uptake (38 to $40 \%$ ), which probably reflects the similarity in both species composition and physiological state of these 2 $\mathrm{N}$-replete communities. At the shallow stratified station (A5), the 2 phytoplankton communities were very similar with respect to $\mathrm{NO}_{3}^{-}$uptake response (60 and $56 \%$ ), but there was a substantial difference between the surface and DCM urea uptake dependency ( 80 and 33 $\%$, respectively). Similar large differences were found for both $\mathrm{NO}_{3}^{-}(60$ and $37 \%$ ) and urea (65 and $28 \%$ ) uptake response in the two communities of the deeply stratified station (T8). It appears that uptake of the regenerated $\mathrm{N}$ source, urea, has a greater dependency on PPFD in the $\mathrm{NO}_{3}^{-}$-replete DCM community, which was effectively isolated from the well-lit surface layers by the strong pycnocline present and normally received only ca 1 to $3 \% \mathrm{I}_{\mathrm{o}}$. The lesser PPFD dependency of the surface phytoplankton may be a consequence of their $\mathrm{N}$-depleted physiological state, which could explain the decrease in PPFD dependency of $\mathrm{NO}_{3}^{-}$uptake in the surface populations of the stratified waters $(60 \%)$ relative to those of the frontal waters (38\%). Alternatively, their decreased PPFD depen-

Table 5. Comparison of half-saturation constants $\left(\mathrm{K}_{\mathrm{LT}}\right)$ for inorganic nitrate transport in various aquatic ecosystems. $\mathrm{I}_{\mathrm{o}}$ : surface photosynthetic photon flux density

\begin{tabular}{|c|c|c|c|c|c|}
\hline \multirow{2}{*}{ Region } & \multirow{2}{*}{ Area } & \multirow{2}{*}{$\begin{array}{l}\text { Depth } \\
\left(\% I_{0}\right)\end{array}$} & \multicolumn{2}{|c|}{$\mathrm{K}_{\mathrm{LT}}\left(\mathrm{NO}_{3}^{-}\right)$} & \multirow{2}{*}{ Source } \\
\hline & & & $\begin{array}{l}\% \text { Surface light } \\
\text { range (mean) }\end{array}$ & $\begin{array}{c}\mu \mathrm{E} \mathrm{m}^{-2} \mathrm{~s}^{-1} \\
\text { range (mean) }\end{array}$ & \\
\hline Oceanic & E Tropical Pacific & 25 & 14.0 & - & Macisaac \& Dugdale (1972) \\
\hline \multirow[t]{2}{*}{ Upwelling } & Peru & 100 & $0.9-12.7 \quad(5.4)$ & $14-108(63)^{\mathrm{a}}$ & MacIsaac \& Dugdale (1972) \\
\hline & & 10 & $0.9-13.3 \quad(8.9)$ & $7-199(122)^{a}$ & \\
\hline Upwelling & Peru & $\begin{array}{r}50 \\
1\end{array}$ & $\begin{array}{l}- \\
-\end{array}$ & $\begin{array}{l}<170-630(\text { ca } 460)^{a} \\
140\end{array}$ & Macisaac et al. (1985) \\
\hline Upwelling & NW Africa & 50 & $1.5-7.0 \quad(5.4)$ & - & MacIsaac et al. (1974) \\
\hline Upwelling & NW Africa & $50-0.1$ & $5.5-6.2 \quad(5.9)$ & - & Nelson \& Conway (1979) \\
\hline Upwelling & Baja Calif., Mexico & $50-3$ & $3.3-32.4(16.1)$ & - & Nelson \& Conway (1979) \\
\hline Upwelling & Antarctic Sea & $\begin{array}{l}50-25 \\
7\end{array}$ & $\begin{array}{l}1.1-2.3 \quad(1.7) \\
1.3\end{array}$ & $\begin{array}{l}2.3-4.4(3.3)^{\mathrm{b}} \\
2.8^{\mathrm{b}}\end{array}$ & Slawyk (1979) \\
\hline Coastal & Peru & $\begin{array}{r}100 \\
10\end{array}$ & $\begin{array}{l}4.4 \\
1.0\end{array}$ & $\begin{array}{l}45 \\
14\end{array}$ & Macisaac \& Dugdale (1972) \\
\hline Coastal & Delaware Estuary, USA & $100-50$ & - & $60-569$ (258) & Pennock (1987) \\
\hline Coastal & Strait of Georgia & $\begin{array}{l}100-80 \\
\text { ca } 8-2\end{array}$ & $\begin{array}{ll}4.6-8.2 & (6.5) \\
1.8-14 & (6.9)\end{array}$ & $\begin{array}{ll}45-91 & (70) \\
18-156 & (76)\end{array}$ & Present study \\
\hline Coastal & Auke Bay, Alaska, USA & - & - & $23.9-261(92.4)$ & Kanda et al. (1989) \\
\hline Freshwater & Toolik L., Alaska, USA & ca $15-10$ & $6-31 \quad(15)$ & $7-29(16)$ & Whalen \& Alexander (1984) \\
\hline Freshwater & L. Kinneret, Israel & - & - & 77 & Berman et al. (1984) \\
\hline Freshwater & L. Biwa, Japan & 100 & 4.29 & $70.8^{\mathrm{c}}$ & Mitamura (1986) \\
\hline Freshwater & Castle L., Calif., USA & $\begin{array}{l}\text { ca } 50 \\
\text { ca } 1\end{array}$ & $\begin{array}{ll}2.6-2.7 & (2.65) \\
0.6-3.7 & (1.55)\end{array}$ & $\begin{array}{l}15.1-16.2(15.7)^{\mathrm{d}} \\
4.6-25.5(10.7)^{\mathrm{d}}\end{array}$ & Priscu (1984) \\
\hline Freshwater & L. Fryxell, Antarctica & 0.4 & 0.08 & $0.38^{\mathrm{e}}$ & Priscu (1989) \\
\hline $\begin{array}{l}\text { a Values calc } \\
{ }^{b} \text { Values calc } \\
{ }^{c} \text { Values calc } \\
{ }^{\mathrm{d}} \text { Values calc } \\
{ }^{\mathrm{e}} \text { Corrected }\end{array}$ & $\begin{array}{l}\text { ulated by converting from } \\
\text { ulated by converting from } \\
\text { ulated by converting from } \\
\text { ulated from total PPFD du } \\
\text { value (Priscu pers. comm.) }\end{array}$ & $\begin{array}{l}\text { langleys } \mathrm{m} \\
\text { quanta } \mathrm{m}^{-} \\
\text {Kilolux usi } \\
\text { ring incuba }\end{array}$ & $\begin{array}{l}\operatorname{nin}^{-1} \text { using } 1 \text { langle } \\
-2 \mathrm{~h}^{-1} \text { using } 1 \text { quan } \\
\text { ing } 1 \text { Kilolux }=16.5 \\
\text { ation periods (ca } 12\end{array}$ & $\begin{array}{l}\operatorname{nin}^{-1}=3485 \mu \mathrm{E} \mathrm{m}^{-2} \\
\mathrm{~m}^{-2} \mathrm{~h}^{-1}=4.614 \times 1 \\
\mathrm{~m}^{-2} \mathrm{~s}^{-1} \text { (Richardsor }\end{array}$ & $\begin{array}{l}-1 \text { (Richardson et al. 1983) } \\
-22 \mu \mathrm{E} \mathrm{m}^{-2} \mathrm{~s}^{-1} \text { (Lüning 1981) } \\
\text { et al. 1983) }\end{array}$ \\
\hline
\end{tabular}


dency may be attributed merely to an accumulation of stored energy and $\mathrm{C}$ skeletons produced during photosynthesis. One cannot directly compare the uptake responses of urea and nitrate in the surface waters, due to differences in ${ }^{15} \mathrm{~N}$ enrichment (saturating vs trace). At the DCM, however, saturating concentrations of $\mathrm{NO}_{3}^{-}$were present during all the uptake experiments, and it appears that the phytoplankton in the stratified DCM communities had a similar degree of PPFD dependency for both saturated $\mathrm{NO}_{3}^{-}$and urea uptake.

\section{Dark nitrogen uptake}

Nitrate and urea uptake occurred in the dark in both frontal and stratified waters (Table 3). In the stratified surface waters (A5, T8), the relative contribution of dark $\mathrm{NO}_{3}^{-}$uptake to total $\mathrm{NO}_{3}^{-}$uptake under saturating PPFD was ca $50 \%$, while in the surface waters of the frontal station (T14) the dark uptake contribution was only $28 \%$ (Table 4 ). At the deeply stratified station (T8), there was no dark $\mathrm{NO}_{3}^{-}$uptake by the DCM population, whereas the relative dark $\mathrm{NO}_{3}^{-}$uptake at the shallow stratified (A5) and frontal (T14) DCM communities was similar to that of their respective surface phytoplankton communities (49 and $25 \%$ ). Dark uptake of urea was also a substantial portion of total urea uptake, averaging 16 and $68 \%$ for the DCM and surface communities, respectively.

Dark N uptake by phytoplankton is not uncommon; a summary of literature values for the ratio of dark:light (total) $\mathrm{N}$ uptake rates $\left(\mathrm{V}_{\mathrm{D}}: \mathrm{V}_{\mathrm{L}}\right.$; dark incubation bottles: clear incubation bottles) for natural phytoplankton assemblages is shown in Table 6. It is important to realize that dark uptake by phytoplankton is a function of incubation time; the rate of dark uptake will likely decrease, relative to light uptake, as incubation time increases and stored energy reserves are depleted. Nevertheless, a review of the literature permits 2 generalizations to be made concerning dependence of light for $\mathrm{N}$ uptake: (1) in N-impoverished waters, the $V_{D}: V_{L}$ ratio is greater (approaching unity) than in $N$ replete waters, suggesting the enhancement of dark uptake by nutrient stress; (2) $\mathrm{V}_{\mathrm{D}}: \mathrm{V}_{\mathrm{L}}$ ratio is generally greater (closer to unity) in samples collected from and incubated under lower PPFD, suggesting a lesser dependence of light for $\mathrm{N}$ uptake with increasing depth in the euphotic zone. The first suggestion is not new, as many laboratory experiments have shown that $\mathrm{N}$ deprivation enhances the uptake of $\mathrm{N}$ to a greater degree in the dark than in the light (e.g. Syrett 1962, Thacker \& Syrett 1972, Harrison 1976, Rees \& Syrett 1979, Paasche et al. 1984). The ability to take up nitrogen in the dark, however, may be species dependent; for example, Eppley et al. (1971) showed that although a somewhat $\mathrm{N}$-depleted tropical oceanic coccolithophorid (Emiliana huxleyi) took up nitrate in the dark, a similarly N-depleted coastal diatom (Skeletonema costatum) did not. Also, whether or not a species is able to take up a significant amount of nitrogen at night or in the dark may depend on its degree of $\mathrm{N}$ depletion. This has been suggested for nitrate-limited continuous cultures of Chaetoceros spp. (Malone et al. 1975) and Micromonas pusilla (Cochlan 1989); at the lower dilution rates, nitrate uptake was continuous and independent of the natural light/dark cycle, but there was diel periodicity in nitrate uptake at the higher dilution rates. It should be noted that the dark uptake rates reported in the present study and used in the ratios of Table 6 were determined during daytime and may not necessarily reflect the uptake rates observed during the night.

During 24-h time-course experiments conducted in frontal waters similar to those referred to in the present study, Price et al. (1985) observed a constancy in $\mathrm{V}_{\mathrm{D}}: \mathrm{V}_{\mathrm{L}}$ for $\mathrm{NH}_{4}^{+}$, although $\mathrm{NH}_{4}^{+}$uptake rates of phytoplankton exposed to the natural light/dark cycle were periodic, suggesting that $\mathrm{NH}_{4}^{+}$uptake in frontal waters was circadian; in absence of the light/dark cycle the rhythm is free-running (see Chisholm 1981). The conclusion of Price et al. (1985) is supported by Goering et al. (1964), who found rhythmic variation in both potential $\mathrm{NH}_{4}^{+}$ and $\mathrm{NO}_{3}^{-}$uptake rates by surface phytoplankton communities of the Sargasso Sea under continuous illumination. However, in the stratified waters of the Strait of Georgia, Price et al. (1985) found that $\mathrm{V}_{\mathrm{D}}: \mathrm{V}_{\mathrm{L}}$ for $\mathrm{NO}_{3}^{-}$ and urea demonstrated both diel and diurnal variability. Diurnal (daytime) variability in the $\mathrm{V}_{\mathrm{D}}: \mathrm{V}_{\mathrm{L}}$ of $\mathrm{NH}_{4}^{+}$ uptake by freshwater phytoplankton assemblages of Lake Calado (Fisher et al. 1988) and the South River estuary (Fisher et al. 1982) has also been observed. In the present study, all the experiments were conducted at approximately the same time of day, thereby compensating for any diurnal variability in $\mathrm{N}$ uptake (either independent of or dependent on the daily light cycle) and thus permitting comparisons between stations.

An unknown portion of the dark uptake in the present experiments may also be attributed to marine heterotrophic bacteria. Horstmann \& Hoppe (1981), using the ammonium analogue methylamine $\left({ }^{14} \mathrm{CH}_{3} \mathrm{NH}_{2}\right)$, first demonstrated competitive $\mathrm{NH}_{4}^{+}$ uptake by natural communities of bacteria and phytoplankton in the Baltic Sea. They found that bacteria ( $>0.2 \mu \mathrm{m}$ ) could assimilate up to half the quantity of methylamine as could phytoplankton $(>3 \mu \mathrm{m})$ and that decreasing PPFD increased the methylamine uptake by surface communities of bacteria relative to phytoplankton. By comparing the nitrogen uptake rate of ${ }^{15} \mathrm{NH}_{4}^{+}$with the rate of ${ }^{14} \mathrm{CO}_{2}$ incorporation into protein, Laws et al. (1985) concluded that heterotrophic $\mathrm{N}$ 


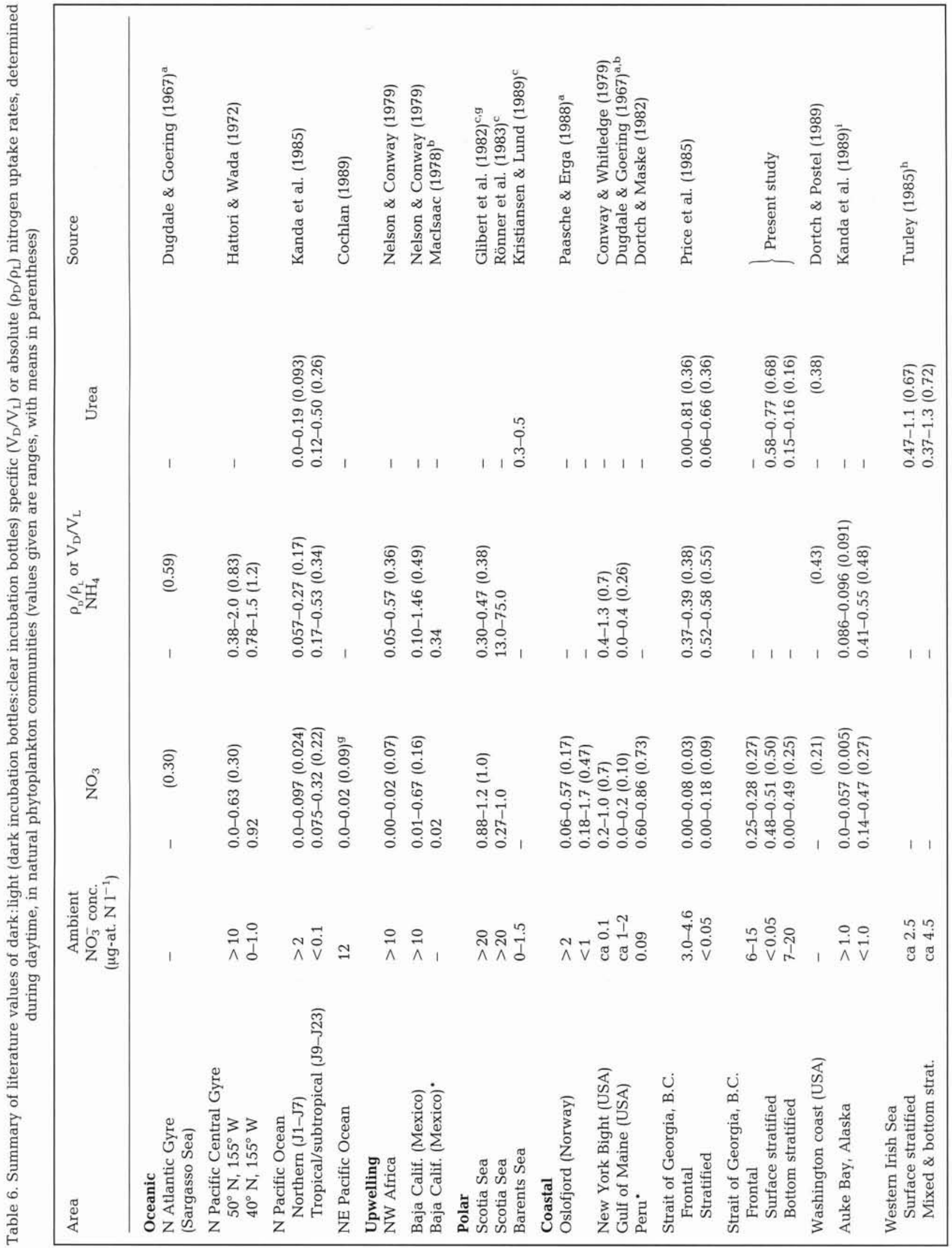




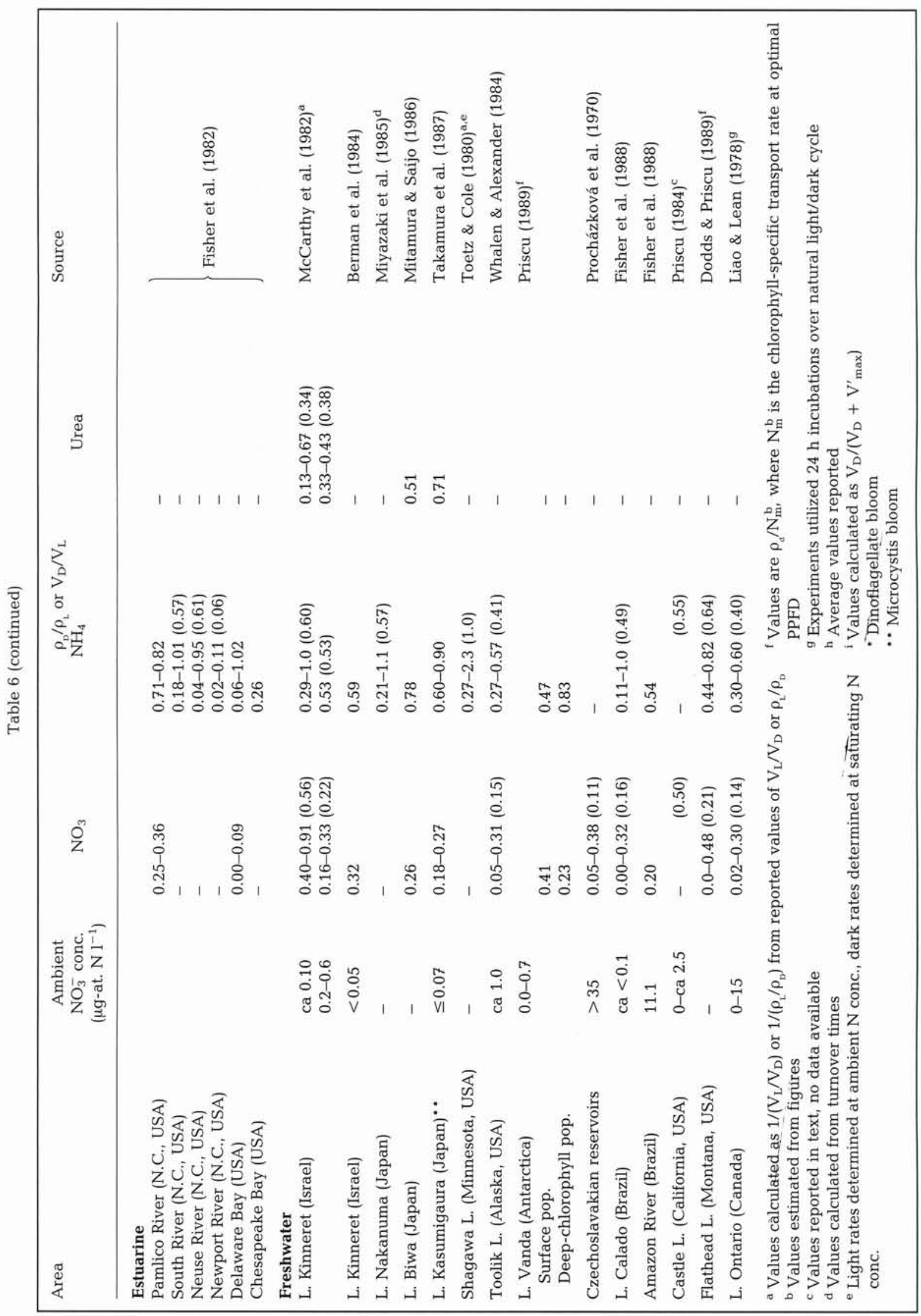


uptake accounted for at least 50 to $75 \%$ of total microbial $\mathrm{N}$ uptake in the waters near the Hawaiian Islands. Similarly, Wheeler \& Kirchman (1986), utilizing metabolic inhibitors, size-fractionation and ${ }^{15} \mathrm{~N}$ methodology, estimated that $78 \pm 22 \%$ of ammonium uptake in the $<1 \mu \mathrm{m}$ size fraction of the surface waters off Georgia was due to bacteria. Brown et al. (1975) reported both $\mathrm{NO}_{3}^{-}$uptake and reduction, and $\mathrm{NH}_{4}^{+}$uptake, by batch cultures of a marine pseudomonad, and Remsen et al. (1972) have demonstrated competition for urea among both bacteria and phytoplankton of the estuaries/coastal waters of Georgia.

In our experiments, Whatman GF/F filters were used to collect particulate material after incubation with ${ }^{15} \mathrm{~N}$ labelled urea and $\mathrm{NO}_{3}^{-}$; these filters do not discriminate completely between bacteria and phytoplankton and can capture 42 to $56 \%$ of the bacteria in marine systems (Lee \& Fuhrman 1987). In the present study, the proportion of inorganic- and organic-N uptake which may be attributed to bacteria is unknown; previous studies in shallow sea frontal systems have reported both greater bacterial biomass and relative heterotrophic activity (as determined by glucose uptake) on the stratified side of a front in Saanich Inlet (Parsons et al. 1983), Liverpool Bay (Floodgate et al. 1981), and the Irish Sea (Egan \& Floodgate 1985, Lochte 1985).

\section{SUMMARY}

The $\mathrm{N}$ uptake response to PPFD of the phytoplankton in the frontal and stratified communities of the Strait of Georgia could be described by a modified MichaelisMenten formulation which included a dark uptake term. Dark uptake of nitrate and urea was a substantial portion of total uptake in these phytoplankton communities, and should be considered in PPFD-dependent uptake models. In the frontal waters, dependency on PPFD for $\mathrm{NO}_{3}^{-}$uptake was similar for both surface and DCM communities, whereas in the stratified waters, surface phytoplankton exhibited less PPFD dependency than those from the DCM, particularly for urea uptake. The dramatic difference in species composition of the phytoplankton communities - from those dominated by large, chain-forming diatoms in the $\mathrm{N}$-replete frontal waters to those composed primarily of microflagellates in the N-depleted stratified waters - probably contributed to the observed variability in their PPFD response and precludes a simple explanation of PPFD effect(s) on $\mathrm{N}$ uptake based merely on phytoplankton $\mathrm{N}$ status. Clearly, more detailed studies on the response of $\mathrm{N}$ uptake to PPFD in unialgal (and axenic) phytoplankton cultures, at various degrees of $\mathrm{N}$ deficiency, need to be conducted before the effect(s) of $\mathrm{N}$ limitation on the $\mathrm{N}$ uptake response to PPFD can be adequately explained.
Acknowledgements. We gratefully acknowledge Dr G.J. Doucette for his assistance at sea and for counting the phytoplankton samples. We thank also the officers and crew of the CSS 'Vector'. This research was supported by a Strategic Grant from the Natural Sciences and Engineering Research Council of Canada, awarded to Drs P.J. Harrison and T.R. Parsons. W.P.C. received funding from a Graduate Research, Engineering and Technology scholarship from the province of British Columbia and a postgraduate fellowship from the University of British Columbia; N.M.P. received funding from a N.S.E.R.C. postgraduate scholarship and a Killam predoctoral fellowship. Comments on a penultimate draft of this manuscript by Drs Y. Collos, J.J. Goering and J.C. Priscu were very helpful.

\section{LITERATURE CITED}

Berman, T., Sherr, B. F., Sherr, E., Wynne, D., McCarthy, J. J. (1984). The characteristics of ammonium and nitrate uptake by phytoplankton in Lake Kinneret. Limnol. Oceanogr. 29: 287-297

Brown, C. M., MacDonald-Brown, D. S., Stanley, S. O. (1975). Inorganic nitrogen metabolism in marine bacteria: nitrate uptake and reduction in a marine pseudomonad. Mar. Biol. 31: 7-13

Chisholm, S. M. (1981). Temporal patterns of cell division in unicellular algae. In: Platt, T. (ed.) Physiological bases of phytoplankton ecology. Can. Bull. Fish. aquat. Sciences 210: 150-181

Cochlan, W. P. (1989). Nitrogen uptake by marine phytoplankton: the effects of irradiance, nitrogen supply and diel periodicity. Ph.D. thesis, Dept. Oceanogr., Univ. of British Columbia, Vancouver

Collos, Y. (1987). Calculation of ${ }^{15} \mathrm{~N}$ uptake rates by phytoplankton assimilating one or several nitrogen sources. Int. J. appl. Radiat. Isotopes 38: 275-282

Conway, H. L., Whitledge, T. E. (1979). Distribution, fluxes and biological utilization of inorganic nitrogen during a spring bloom in the New York Bight. J. mar. Res. 37: 657-668

Denman, K. L., Powell, T. M. (1984). Effects of physical processes on planktonic ecosystems in the coastal ocean. Oceanogr. mar. Biol. A. Rev. 22: 125-168

Dodds, W. K., Priscu, J. C. (1989). Ammonium, nitrate, phosphate, and inorganic carbon uptake in an oligotrophic lake: seasonal variations among light response variables. J. Phycol. 25: 699-705

Dortch, Q., Maske, H. (1982). Dark uptake of nitrate and nitrate reductase activity of a red-tide population off Peru. Mar. Ecol. Prog. Ser. 9: 299-303

Dortch, Q., Postel, J. R. (1989). Phytoplankton-nitrogen interactions. In: Landry, M. R., Hickey, B. M. (eds.) Coastal oceanography of Washington and Oregon. Elsevier Science Publishers, Amsterdam, p. 139-173

Dugdale, R. C., Goering, J. J. (1967). Uptake of new and regenerated forms of nitrogen in primary productivity. Limnol. Oceanogr. 12: 196-206

Dugdale, R. C., Wilkerson, F. P. (1986). The use of ${ }^{15} \mathrm{~N}$ to measure nitrogen uptake in eutrophic oceans; experimental considerations. Limnol. Oceanogr. 31: 673-689

Egan, B., Floodgate, G. D. (1985). Biological studies in the vicinity of a shallow-sea tidal mixing front. II. The distribution of bacteria. Phil. Trans. R. Soc. (Ser. B) 310: 435-444

Eppley R. W., Coatsworth, J. L. (1968). Uptake of nitrate and nitrite by Ditylum brightwellii - kinetics and mechanisms. J. Phycol. 4: 151-156

Eppley, R. W., Rogers, J. N., McCarthy, J. J., Sournia, A. (1971). 
Light/dark periodicity in nitrogen assimilation of the marine phytoplankters Skeletonema costatum and Coccolithus huxleyi in N-limited chemostat cultures. J. Phycol. 7: $150-154$.

Falkowski, P. G. (1975a). Nitrate uptake in marine phytoplankton: (nitrate, chloride)-activated adenosine triphosphatase from Skeletonema costatum (Bacillariophyceae). J. Phycol. 11: $323-326$

Falkowski, P. G. (1975b). Nitrate uptake in marine phytoplankton: comparison of half-saturation constants from seven species. Limnol. Oceanogr. 20: 412-417

Fiedler, R., Proksch, G. (1975). The determination of nitrogen15 by emission and mass spectrometry in biochemical analysis: a review. Analytica chim. Acta 78: 1-62

Fisher, T. R., Carlson, P. R., Barber, R. T. (1982). Carbon and nitrogen primary productivity in three North Carolina estuaries. Estuar. coast. Shelf Sci. 15: 621-644

Fisher, T. R., Morrissey, K. M., Carlson, P. R., Alves, L. F., Melack, J. M. (1988). Nitrate and ammonium uptake by plankton in an Amazon River floodplain lake. J. Plankton Res. 10: 7-29

Floodgate, G. D., Fogg, G. E., Jones, D. A., Lochte, K., Turley, C. M. (1981). Microbiological and zooplankton activity at a front in Liverpool Bay. Nature, Lond. 209: 133-136

Glibert, P. M., Biggs D. C., McCarthy, J. J. (1982). Utilization of ammonium and nitrate during austral summer in the Scotia Sea. Deep Sea Res. 29: 837-850

Goering, J. J., Dugdale, R. C., Menzel, D. W. (1964). Cyclic diurnal variations in the uptake of ammonia and nitrate by photosynthetic organisms in the Sargasso Sea. Limnol. Oceanogr. 9: 448-451

Hansell, D. A., Goering, J. J. (1989). A method for estimating uptake and production rates for urea in seawater using $\left[{ }^{14} \mathrm{C}\right]$ urea and $\left[{ }^{15} \mathrm{~N}\right]$ urea. Can. J. Fish. aquat. Sciences 46 : 198-202

Harrison, P. J., Fulton, J. D., Taylor, F. J. R., Parsons, T. R. (1983). Review of the biological oceanography of the Strait of Georgia: pelagic environment. Can. J. Fish. aquat. Sci. 40: $1064-1094$

Harrison, W. G. (1976). Nitrate metabolism of the red tide dinoflagellate Gonyaulax polyedra. J. exp. mar. Biol. Ecol. 21: 199-209

Hattori, A., Wada, E. (1972). Assimilation of inorganic nitrogen in the euphotic layer of the North Pacific Ocean. In: Takenouth, A.K. (ed.) Biological oceanography of the northern North Pacific Ocean. Idemitsu Shoten, Tokyo, p. 279-287

Holligan, P. M., Williams, P. J. leB., Purdie, D., Harris, R. P. (1984). Photosynthesis, respiration and nitrogen supply of plankton populations in stratified, frontal and tidally mixed shelf waters. Mar. Ecol. Prog. Ser. 17: 201-213

Horstmann, U., Hoppe, H.G. (1981). Competition in the uptake of methylamine/ammonium by phytoplankton and bacteria. Kieler Meeresforsch. (Sondh.) 5: 110-116

Jones, D. M., Harrison, P. J., Clifford, P. J., Yin, K. (in press). A simple, inexpensive verticle profiling system for continuous measurement of temperature, salinity, fluorescence and selected nutrients. Wat. Res.

Kanda, J., Saino, T., Hattori, A. (1985). Nitrogen uptake by natural populations of phytoplankton and primary production in the Pacific Ocean: regional variability of uptake capacity. Limnol. Oceanogr. 30: 987-999

Kanda, J., Ziemann, D. A., Conquest, L. D., Bienfang, P. K. (1989). Light-dependency of nitrate uptake by phytoplankton over the spring bloom in Auke Bay, Alaska. Mar. Biol. 103: 563-569

Kristiansen, S., Lund, B. A. (1989). Nitrogen cycling in the
Barents Sea. I. Uptake of nitrogen in the water column. Deep Sea Res. 36: 255-268

La Roche, J. (1983). Ammonium regeneration: its contribution to phytoplankton nitrogen requirements in a eutrophic environment. Mar. Biol. 75: 231-240

Laws, E. A., Harrison, W. G., DiTullio, G. R. (1985). A comparison of nitrogen assimilation rates based on ${ }^{15} \mathrm{~N}$ uptake and autotrophic protein synthesis. Deep Sea Res. 32: 85-95

LeBlond, P. H. (1983). The Strait of Georgia: functional anatomy of a coastal sea. Can. J. Fish. Aquat. Sci. 40: 1033-1063

Lee, S., Fuhrman, J. A. (1987). Relationships between biovolume and biomass of naturally derived marine bacterioplankton. Appl. environ. Microbiol. 53: 1298-1303

LeFèvre, J. (1986). Aspects of the biology of frontal systems. Adv. mar. Biol. 23: 163-299

Lewis, W. M., Levine, S. N. (1984). The light response of nitrogen fixation in Lake Valencia, Venezuela. Limnol. Oceanogr. 29: 894-900

Liao, C. F.-H., Lean, D. R. S. (1978). Nitrogen transformations within the trophogenic zone of lakes. J. Fish. Res. Bd Can. 35: $1102-1108$

Lochte, K. (1985). Biological studies in the vicinity of a shallow-sea tidal mixing front. III. Seasonal and spatial distribution of heterotrophic uptake of glucose. Phil. Trans. R. Soc. (Ser. B) 310: 445-469

Lüning, K. (1981). Light. In: Lobban, C. S., Wynne, M. J. (eds.) Botanical monographs, Vol. 17. The biology of seaweeds. Univ, of Calif. Press, Berkeley, California, p. 326-355

MacIsaac, J. J. (1978). Diel cycles of inorganic nitrogen uptake in a natural phytoplankton population dominated by Gonyaulax polyedra. Limnol. Oceanogr. 23: 1-9

MacIsaac, J. J., Dugdale, R. C. (1969). The kinetics of nitrate and ammonia uptake by natural populations of marine phytoplankton. Deep Sea Res. 16: 45-57

MacIsaac, J. J., Dugdale, R. C. (1972). Interactions of light and inorganic nitrogen in controlling nitrogen uptake in the sea. Deep Sea Res. 19: 209-232

MacIsaac, J. J., Dugdale, R. C., Barber, R. T., Blasco, D., Packard, T. T. (1985). Primary production in an upwelling center. Deep Sea Res. 32: 503-529

MacIsaac J. J., Dugdale, R. C., Slawyk, G. (1974). Nitrogen uptake in the northwest Africa upwelling area: results from the Cineca-Charcot II cruise. Téthys 6: 69-76

Malone, T. C., Garside, C., Haines, K. C., Roels, O. A. (1975). Nitrate uptake and growth of Chaetoceros sp. in large outdoor cultures. Limnol. Oceanogr. 20: 9-19

McCarthy, J. J., Taylor, W. R., Taft, J. L. (1977). Nitrogenous nutrition of the plankton in the Chesapeake Bay. I. Nutrient availability and phytoplankton preferences. Limnol. Oceanogr. 22: 996-1011

McCarthy, J. J., Wynne, D., Berman, T. (1982). The uptake of dissolved nitrogenous nutrients by Lake Kinneret (Israel) microplankton. Limnol. Oceanogr. 27: 673-680

Mitamura, O. (1986). Urea metabolism and its significance in the nitrogen cycle in the euphotic layer of Lake Biwa. III. Influence of the environmental parameters on the response of nitrogen assimilation. Arch. Hydrobiol. 107: 281-299

Mitamura, O., Saijo, Y. (1986). Urea metabolism and its significance in the nitrogen cycle in the euphotic layer of Lake Biwa. I. In situ measurements of nitrogen assimilation and urea decomposition. Arch. Hydrobiol. 107: 23-51

Miyazaki, T., Honjo, Y., Inchimura, S. (1985). Uptake of carbon and inorganic nitrogen in a eutrophic lake, Lake Nakanuma, Japan, from spring through summer. Arch. Hydrobiol. 102: 473-485 
Nelson, D. M., Conway, H. L. (1979). Effects of the light regime on nutrient assimilation by phytoplankton in the Baja California and northwest Africa upwelling systems. J. mar. Res, 37: 301-318

Paasche, E., Bryceson, I., Tangen, K. (1984). Interspecific variation in dark nitrogen uptake by dinoflagellates. J. Phycol. 20: 394-401

Paasche, E., Erga, S. R. (1988). Phosphorus and nitrogen limitation of phytoplankton in the inner Oslofjord (Norway). Sarsia 73: 229-243

Parker, R. A. (1974). Empirical functions relating metabolic processes in aquatic systems to environmental variables. J. Fish. Res. Bd Can. 31: 1550-1552

Parsons, T. R., Maita, Y., Lalli, C. M. (1984). A manual of chemical and biological methods for seawater analysis. Pergamon Press, Oxford

Parsons, T. R., Perry, R. I., Nutbrown, E. D., Hsieh, W., Lalli, C. M. (1983). Frontal zone analysis at the mouth of Saanich Inlet, British Columbia, Canada. Mar. Biol. 73: 1-5

Parsons, T. R., Stronach, J., Borstad, G. A., Louttit, G., Perry, R. I. (1981). Biological fronts in the Strait of Georgia, British Columbia, and their relation to recent measurements of primary productivity. Mar. Ecol. Prog. Ser. 6: 237-242

Pennock, J. R. (1987). Temporal and spatial variability in phytoplankton ammonium and nitrate uptake in the Delaware Estuary. Estuar. coast. Shelf Sci. 2: 841-857

Pingree, R. D., Pugh, P. R., Holligan, P. M., Forster, G. R. (1975). Summer phytoplankton blooms and red tides along tidal fronts in the approach to the English Channel. Nature, Lond. 258: 672-677

Platt, T., Gallegos, C. L., Harrison, W. G. (1980). Photoinhibition of photosynthesis in natural assemblages of marine phytoplankton. J. mar. Res. 38: 687-701

Price, N. M., Cochlan, W. P., Harrison, P. J. (1985). Time course of uptake of inorganic and organic nitrogen by phytoplankton in the Strait of Georgia: comparison of frontal and stratified communities. Mar. Ecol. Prog. Ser. 27: $39-53$

Price, N. M., Harrison, P. J. (1987). A comparison of methods for the measurement of dissolved urea concentrations in seawater. Mar. Biol. 92: 307-319

Priscu, J. C. (1984). A comparison of nitrogen and carbon metabolism in the shallow and deep-water phytoplankton populations of a subalpine lake: response to photosynthetic photon flux density. J. Plankton Res. 6: 733-749

Priscu, J. C. (1989). Photon dependence of inorganic nitrogen transport by phytoplankton in perennially ice-covered Antarctic lakes. In: Vincent, W.F., Ellis-Evans, J.C. (eds.) High latitude limnology. Hydrobiologia (spec. issue) 172: 173-182

Probyn, T. A. (1985). Nitrogen uptake by size-fractionated phytoplankton populations in the southern Benguela upwelling system. Mar. Ecol. Prog. Ser. 22: 249-258

Procházková, L., Blazka, B., Králová, M. (1970). Chemical changes involving nitrogen metabolism in water and particulate matter during primary production experiments. Limnol. Oceanogr. 15: 797-807

Rees, T. A. V., Syrett, P. J. (1979). The uptake of urea by the diatom Phaeodactylum. New Phytol. 82: 169-178

Remsen, C. C., Carpenter, E. J., Schroeder, B. W. (1972). Competition for urea among estuarine microorganisms. Ecology 53: 921-926

This article was presented by Dr T. Platt, Dartmouth, N.S., Canada
Richardson, K., Beardall, J., Raven, J. A. (1983). Adaptation of unicellular algae to irradiance: an analysis of strategies. New Phytol. 93: 157-191

Rönner, U., Sörensson, F. Holm-Hansen, O. (1983). Nitrogen assimilation by phytoplankton in the Scotia Sea. Polar Biol. 2: $137-147$

Sharp, J. H. (1974). Improved analysis for 'particulate organic carbon and nitrogen' from seawater. Limnol. Oceanogr. 19: $984-989$

Simpson, J. H. Pingree, R. D. (1978). Shallow sea fronts produced by tidal stirring. In: Bowman, M.J., Esaias, W.E. (eds.) Oceanic fronts in coastal processes. Springer-Verlag, Berlin, p. 29-42

Slawyk, G. (1979). ${ }^{13} \mathrm{C}$ and ${ }^{15} \mathrm{~N}$ uptake by phytoplankton in the Antarctic upwelling area: results from the Antiprod I cruise in the Indian Ocean sector. Aust. J. mar. Freshwat. Res. 30: $431-438$

Slawyk, G., MacIsaac, J. J. (1972). Comparison of two automated ammonium methods in a region of coastal upwelling. Deep Sea Res. 19: 521-524

Slawyk, G., MacIsaac, J. J., Dugdale, R. C. (1976). Inorganic nitrogen uptake by marine phytoplankton under in situ and simulated in situ incubation conditions: results from the northwest African upwelling region. Limnol. Oceanogr. 21: 149-152

Strickland, J. D. H., Parsons, T. R. (1972). A practical handbook of seawater analysis, 2nd edn. Bull. Fish. Res. Bd Can. 167: 1-310

Syrett, P. J. (1962). Nitrogen assimilation. In: Lewin, R.A. (ed.) Physiology and biochemistry of algae. Academic Press, New York, p. 171-188

Syrett, P. J. (1981). Nitrogen metabolism of microalgae. In: Platt, T. (ed.) Physiological bases of phytoplankton ecology. Can. Bull. Fish. aquat. Sci. 210: 182-210

Takamura, N., Iwakuma, T., Yasuno, M. (1987). Uptake of ${ }^{13} \mathrm{C}$ and ${ }^{15} \mathrm{~N}$ (ammonium, nitrate and urea) by Microcystis in Lake Kasumigaura. J. Plankton Res. 9: 151-165

Thacker, A., Syrett, P. J. (1972). The assimilation of nitrate and ammonium by Chlamydomonas reinhardi. New Phytol. 71: 423-433

Toetz, D., Cole, B. (1980). Ammonia mineralization and cycling in Shagawa Lake, Minnesota. Arch. Hydrobiol. 88: 9-23

Turley, C. M. (1985). Biological studies in the vicinity of a shallow-sea tidal mixing front. IV. Seasonal and spatial distribution of urea and its uptake by phytoplankton. Phil. Trans. R. Soc. (Ser. B) 310: 471-500

Utermöhl, H. (1958). Zur vervollkommung der quantitativen phytoplankton methodik. Mitt. int. Verein theor. angew. Limnol. 9: 1-38

Webb, K. L., Haas, L. W. (1976). The significance of urea for phytoplankton nutrition in the York River, Virginia. In: M. Wiley (ed.) Estuarine processes, Vol. I. Academic Press, New York, p. 90-102

Whalen, S. C., Alexander, V. (1984). Influence of temperature and light on rates of inorganic nitrogen transport by algae in an arctic lake. Can. J. Fish. aquat. Sci. 41: 1310-1318

Wheeler, P. A., Kirchman, D. L. (1986). Utilization of inorganic and organic nitrogen by bacteria in marine systems. Limnol. Oceanogr. 31: 998-1009

Wood, E. D., Armstrong, F. A. J., Richards, F. A. (1967). Determination of nitrate in seawater by cadmium-copper reduction to nitrite. J. mar. biol. Ass. U.K. 47: 23-31 